
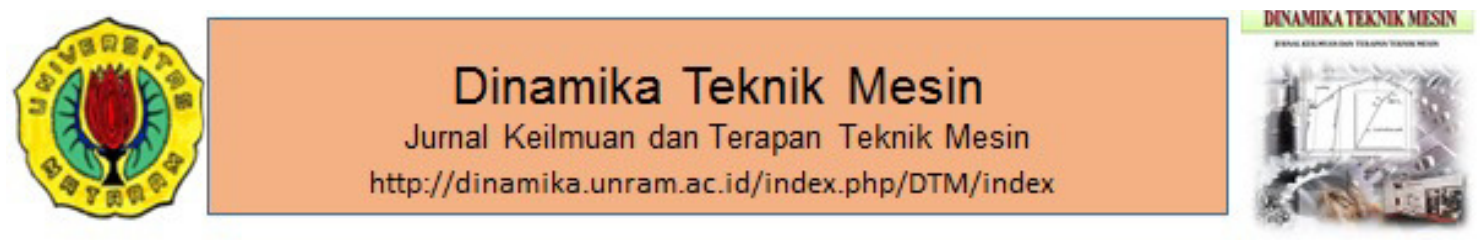

\title{
Investigasi simulasi numeris dan eksperimen proses springback berbentuk cup silider pada lembaran baja karbon SPCC
}

\section{Numerical simulation and experimental investigation of springback process of carbon steel SPCC sheet shaped cylinder cup}

\section{B. Mulyanto*1 D.S. Khaerudini ${ }^{{ }^{1,2}}$}

${ }^{1}$ Program Magister Teknik Mesin, Fakultas Teknik, Universitas Mercu Buana Jakarta 11610

${ }^{2}$ Pusat Penelitian Fisika, Lembaga IImu Pengetahuan Indonesia, Puspiptek Serpong Banten 15314

*E-mail: mazbam01@gmail.com

\section{ARTICLE INFO}

Article History:

Received 02 September 2019

Accepted 20 December 2019

Available online 1 April 2020

Keywords:

Spring-back

Ironing

Cup cylinder

Carbon steel SPCC

SMF

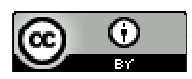

ABSTRACT

The sheet metal forming (SMF) process is one of the manufacturing processes that important and commonly used in the automotive industry. Compared with casting and forging, forming process into the metal sheet obtain several advantages including fewer weight materials and variations in shapes that can be made. One of the challenges in the SMF process is the spring-back phenomenon which can cause a deviation in the size of sheet products. The springback occurs due to the reverse force phenomena due to the effect of its elasticity of sheet carbon steel material that has experienced the formation process. Ironing of SPCC sheet metal with a thickness of 0.8 and $1.0 \mathrm{~mm}$ is carried out in a pressure of $2.9 \mathrm{MPa}$ with die velocity $60 \mathrm{~mm} / \mathrm{sec}$. The experimental data that carried out with a single die on the cup cylinder sample test showed that the lower the value of ironing, the greater the value of the spring-back material. Therefore, the spring-back phenomenon can be reduced 0.03 to $0.07 \mathrm{~mm}$ by engineering the ironing process with a range of $0.15 \mathrm{~mm}$

\section{PENDAHULUAN}

Sheet metal forming (SMF) adalah proses pembentukan lembaran logam yang dibuat dengan menggunakan dies dan mesin press. Proses SMF menggunakan satu dies dalam satu langkah (combination dies) atau menggunakan beberapa rakitan dies (progressive dies, transfer dies) dalam satu langkah tekan (Boljanovic, 2004). Salah satu fenomena yang muncul pada SMF adalah 
Dinamika Teknik Mesin. Mulyanto dan Khaerudini: Investigasi simulasi numeris dan eksperimen proses springback berbentuk cup silider pada lembaran baja karbon SPCC

springback. Efek dari springback adalah terjadi peyimpangan ukuran dari produk pembentukan, oleh karena itu harus direduksi agar proses menjadi lebih efisien.

Setiap proses pembentukan lembaran logam (SMF) melibatkan pembentukan elastis dan kemudian diikuti oleh deformasi plastik permanen. Karena adanya sifat elastis logam, setelah produk terlepas dari die dan punch, fenomena springback elastis selalu terjadi menghasilkan produk yang terbentuk di luar target. Springback adalah deviasi dimensi karena elastisitas lembaran logam selama pembentukan dan setelah pembentukan (Wagoner dkk., 2013).

Springback merupakan gaya balik yang disebabkan pengaruh elastisitas bahan pelat yang mengalami proses pembentukan. Besarnya gaya balik ini ditentukan oleh harga modulus elastisitas bahan (Boljanovic, 2004). Dalam proses bending ini harus diperhatikan gaya balik atau springback seperti ditunjukkan pada gambar 1 . Springback mengakibatkan terjadinya penyimpangan terhadap sudut bending dan mengakibatkan bahan produk hasil bending dapat mengalami penyimpangan ukuran.

Aplikasi sederhana seperti pada proses bending dengan sudut $90^{\circ}$ maka besarnya sudut tekan pada die dan punch bending harus lebih kecil dari $90^{\circ}$, sehingga pada saat kondisi lepas dari die dan punch bending menghasilkan sudut produk yang sama dengan $90^{\circ}$. Besarnya perubahan ukuran pada hasil pembentukan setelah tekanan pembentukan ditiadakan (dilepaskan) mencerminkan karakteristik elastisitas bahan baja karbon SPCC tersebut. Jika beban dihilangkan regangan total akan berkurang disebabkan oleh terjadinya pemulihan elastis.Pemulihan elastis merupakan fenomena balikan pegas yang mungkin besar jika tegangan luluh semakin tinggi atau modulus elastis lebih rendah, sehingga regangan plastis semakin besar. Setiap deformasi plastis akan diikuti oleh pemulihan elastis. Sebagai konsekuensi dari fenomena ini adalah terjadi cacat plastis setelah beban dilepaskan.

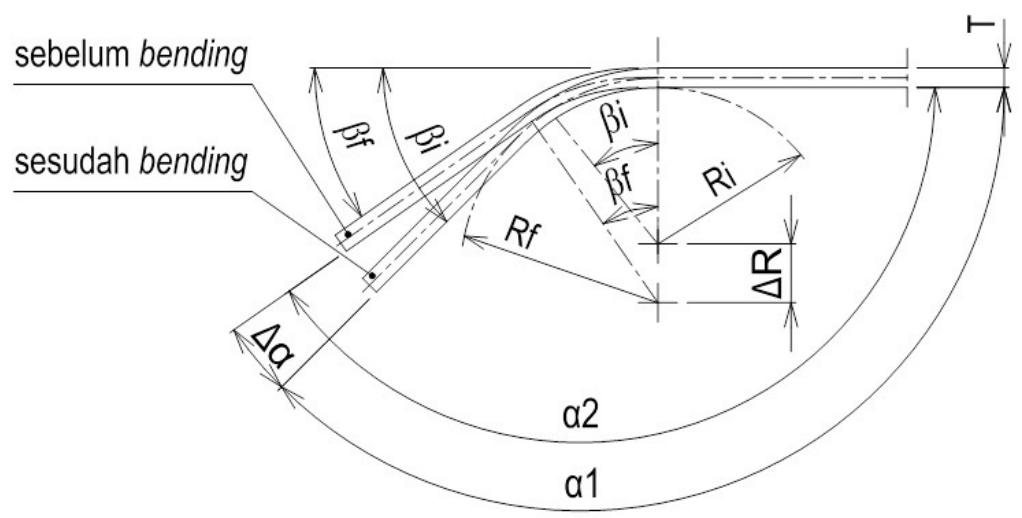

Gambar 1 . Skema springback pada proses bending dengan $R_{\mathrm{i}}$ adalah jari-jari saat bending $(\mathrm{mm}), \beta_{\mathrm{i}}$ adalah sudut saat bending $\left({ }^{\circ}\right), R_{f}$ adalah jari-jari setelah bending $(\mathrm{mm}), \beta_{\mathrm{f}}$ sudut setelah bending $\left(^{\circ}\right)$, $T$ adalah tebal bahan $(\mathrm{mm}), \Delta \mathrm{R}$ adalah perubahan titik pusat jari-jari $(\mathrm{mm}), \alpha 1$ adalah sudut produk saat bending $\left({ }^{\circ}\right)$, $\alpha 2$ adalah sudut produk setelah bending $\left({ }^{\circ}\right)$ dan $\Delta \alpha$ adalah perubahan sudut produk $\left({ }^{\circ}\right)$.

Deformasi permanen $\left(\varepsilon_{t}\right)$ yang terbentuk adalah hasil pengurangan deformasi plastis dengan deformasi elastis yang dihitung menggunakan persamaan (Boljanovic, 2004):

$\varepsilon_{t}=\varepsilon_{p l}-\varepsilon_{e}$

dimana $\varepsilon_{\mathrm{t}}$ adalah deformasi permanen, $\varepsilon_{\mathrm{pl}}$ adalah deformasi plastis dan $\varepsilon_{\mathrm{e}}$ adalah deformasi elastis.

Bila kelonggaran bending pada garis netral $\left(L_{n}\right)$ sebelum dan sesudah bending dianggap sama, maka dapat dihitung dengan persamaan :

$L_{n}=\left[R_{i}+\frac{T}{2}\right] \beta_{i}=\left[R_{f}+\frac{T}{2}\right] \beta_{f}$ 
Dinamika Teknik Mesin. Mulyanto dan Khaerudini: Investigasi simulasi numeris dan eksperimen proses springback berbentuk cup silider pada lembaran baja karbon SPCC

dengan $L_{n}$ adalah garis netral, $R_{\mathrm{i}}$ adalah jari-jari saat bending $(\mathrm{mm}), \beta_{\mathrm{i}}$ adalah sudut saat bending $\left(^{\circ}\right)$, $\mathrm{R}_{\mathrm{f}}$ adalah jari-jari setelah bending $(\mathrm{mm}), \beta_{\mathrm{f}}$ sudut setelah bending $\left({ }^{\circ}\right)$, dan $\mathrm{T}$ adalah tebal bahan $(\mathrm{mm})$.

Faktor springback $\left(\mathrm{K}_{\mathrm{s}}\right)$ dapat dihitung dengan persamaan:

$$
K_{s}=\frac{R_{i}+\frac{T}{2}}{R_{f}+\frac{T}{2}}=\frac{\frac{2 R_{i}}{T}+1}{\frac{2 R_{f}}{T}+1}=\frac{\varphi_{f}}{\varphi_{i}}=\frac{180^{\circ}-\alpha_{2}}{180^{\circ}-\alpha_{1}}
$$

dimana $\alpha 1$ adalah sudut produk saat bending $\left({ }^{\circ}\right)$, a2 adalah sudut produk setelah bending $\left(^{\circ}\right)$ dan $\Delta \alpha$ adalah perubahan sudut produk $\left(^{\circ}\right)$.

Faktor springback $\left(\mathrm{K}_{\mathrm{S}}\right)$ bergantung pada rasio $(\mathrm{R}: \mathrm{T})$ besarnya jari-jari punch $(\mathrm{R})$ dan tebal bahan uji $(\mathrm{T})$. Bila faktor springback $\left(\mathrm{K}_{\mathrm{S}}\right)=1$ artinya tidak ada springback dan bila faktor springback $\left(\mathrm{K}_{\mathrm{S}}\right)=0$ menujukkan bahwa pemulihan elastis telah lengkap (Boljanovic, 2004).

Ironing merupakan proses penipisan dinding bahan pada proses drawing atau deep drawing oleh drawing die atau drawing. Pada proses SMF khususnya drawing dan deep drawing ironing sangat berpengaruh pada fenomena springback karena ironing membatasi deformasi elastis dari bahan uji. Ironing juga mengurangi tegangan sisa yang didistribusikan dengan baik ke sepanjang dinding silider cup punch (Zein dkk., 2014).

Ironing rasio (IR) pada proses SMF dapat dihitung dengan persamaan (Parida dkk., 2016):

$I R=\left[\frac{T_{0}-T_{f}}{T_{0}}\right] x 100$

dimana IR adalah ironing rasio (\%), $\mathrm{T}_{0}$ adalah tebal awal bahan $(\mathrm{mm})$ dan $\mathrm{T}_{\mathrm{f}}$ adalah tebal akhir bahan $(\mathrm{mm})$.

Darmawan dkk. (2018) melakukan simulasi dan eksperimen fenomena springback pada bahan lembaran paduan Aluminium ketebalan $0,32 \mathrm{~mm}$. Simulasi dilakukan dengan Autoform dan eksperimen pada mesin press hidrolik dengan tekanan $1500 \mathrm{kN}$ dengan variasi celah antara bending die dan bending punch. Penelitian dilakukan untuk mengetahui penyimpangan ukuran setelah proses bending.

Mulidran dkk. (2018) melakukan penelitian dengan simulasi dan eksperimen proses $U$ bending pada bahan Tailor welded blank (TWB) tebal 1,0 mm. TWB tersusun dari dua bahan yaitu DC 40 di sisi kiri dan DP 1200 disisi kanan dengan variasi celah drawing die dan punch sebesar 1,2 dan 2,2 mm. Tekanan dudukan blank diatur ke 1,8 MPa, nilai koefisien gesekan f adalah 0,25.

Siswanto dkk. (2014) melakukan penelitian dengan simulasi fenomena springback pada proses $U$ bending material mild steel DC04 tebal $0,8 \mathrm{~mm}$ dengan dua metode berbeda. Penelitian ini bertujuan untuk mengembangkan prosedur kompensasi yang dapat melakukan proses dengan optimal, menggunakan kombinasi konvergensi cepat displacement adjustment (DA) dan metode fleksibel spring forward (SF) sehingga metode kombinasi akan cepat dan berlaku untuk semua permukaan dies. Metode ini memandu proses modifikasi permukaan dies untuk mengkompensasi springback setelah produk terlepas dari dies. Metode gabungan baru ini kemudian disebut kompensasi hybrid method (HM).

Steel plate cold rolled coiled (SPCC) adalah baja karbon yang dibentuk dengan rol dingin dengan kualitas komersial, merujuk pada JIS-G3141 bahan ini berbentuk lembaran untuk proses pengerjaan dingin. Bahan ini paling banyak digunakan dalam industri manufaktur SMF khususnya drawing dan deep drawing dibandingkan dengan bahan jenis lain seperti ASTM (American Society for Testing and Bahans), KS (Korean Steel Standard) atau GB (Guojia Biaozhun-China). Bahan SPCC memiliki kandungan karbon (C) maksimal adalah 0,15\%, Mangan (Mn) 0,6\%, Phospor (P) 0,1 dan Sulpur (S) $0,05 \%$. Tensile strength minimal $270 \mathrm{~N} / \mathrm{mm}^{2}$, yield point minimal $240 \mathrm{~N} / \mathrm{mm}^{2}$, dan elongasi minimal $36 \%$ untuk ketebalan 0,6 sampai $1,0 \mathrm{~mm}$. Bahan jenis ini memiliki nilai batasan penyimpangan ketebalan sebesar $0,06 \mathrm{~mm}$ untuk ketebalan $0,6 \mathrm{~mm}$ sampai $1,0 \mathrm{~mm}$ sehingga 
Dinamika Teknik Mesin. Mulyanto dan Khaerudini: Investigasi simulasi numeris dan eksperimen proses springback berbentuk cup silider pada lembaran baja karbon SPCC

memiliki kemampubentukan yang baik. Pertimbangan lain dalam pemilihan bahan adalah berdasarkan karakteristik awal dari bahan yang memiliki tingkat kemudahan fabrikasi atau dibatasi berdasarkan keinginan untuk mencapai sifat akhir yang diperlukan untuk menyelesaikan proses deformasi.

Aspek yang termasuk adalah, jenis bahan, berat, kekuatan, dan kekakuan sehingga dipilih lembaran logam dari bahan baja kabon SPCC. Penelitian ini melakukan analisis nilai penyimpangan diameter dinding karena gaya balik (springback) pada proses drawing untuk bahan lembaran baja karbon SPCC, dengan morfologi berbentuk cup silider dan ketebalan tertentu yaitu 0,8 dan 1,0 mm dengan metode ironing (Coera dkk., 2018)

\section{METODOLOGI PENELITIAN}

Penelitian Investigasi simulasi numeris dan eksperimen proses springback berbentuk cup silider pada lembaran baja karbon SPCC dengan menerapkan rekayasa ironing pada die dan punch. Teori sederhana proses bending diterapkan untuk memperkirakan nilai springback yang terjadi pada produk uji. Ironing rasio (IR) digunakan untuk menentukan kompensasi springback pada die dan punch.

\subsection{Cetakan (Dies)}

Untuk mengetahui nilai springback yang terjadi pada bahan Baja karbon SPCC berbentuk cup silinder dengan ketebalan 0,8 dan 1,0 mm dilakukan eksperimen menggunakan dies tunggal, yaitu dies yang hanya melakukan satu proses drawing saja seperti gambar 2 berikut ini.

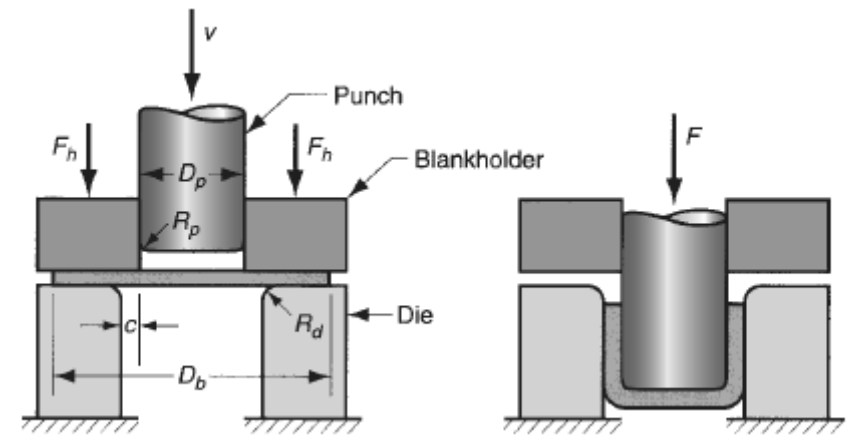

Gambar 2. Proses drawing die tunggal

\subsection{Mesin press}

Eksperimen proses drawing lembaran baja karbon SPCC dengan die tunggal dilakukan pada mesin press $600 \mathrm{kN}$, tekanan 2,9 MPa. Kecepatan langkah mesin press dalam penelitian ini ditetapkan $60 \mathrm{~mm}$ per menit. Spesifikasi mesin press ditunjukkan dalam tabel 1 dibawah ini.

Tabel 1. Spesifikasi mesin press mekanik 600 kN (Aida press hand book, 2010)

\begin{tabular}{ll}
\hline Spesifikasi & Tipe mesin (2)E \\
\hline Kapasitas $(\mathrm{kN})$ & 600 \\
Panjang langkah $(\mathrm{mm})$ & 140 \\
Langkah per menit & $45-85$ \\
Tinggi dies, slide ke bolster $(\mathrm{mm})$ & 300 \\
Slide adjustmen $(\mathrm{mm})$ & 70 \\
Ukuran slide, panjang x lebar $(\mathrm{mm})$ & $480 \times 400$ \\
Ukuran bolster, panjang x lebar $(\mathrm{mm})$ & $870 \times 520$ \\
Frame gap $(\mathrm{mm})$ & 270 \\
Frame inside measurement $(\mathrm{mm})$ & 130 \\
Motor utama & $5.5 \times 4$ \\
Tekanan udara dibutuhkan $(\mathrm{Mpa})$ & 0.5 \\
\hline
\end{tabular}


Dinamika Teknik Mesin. Mulyanto dan Khaerudini: Investigasi simulasi numeris dan eksperimen proses springback berbentuk cup silider pada lembaran baja karbon SPCC

\subsection{Pengukuran}

Pengukuran produk SMF dilakukan dengan dua metode pengukuran yaitu:

1. Pengukuran geometri.

Pengukuran diameter dilakukan pada bagian atas (bagian a) dan bagian bawah (bagian b) produk uji seperti gambar 3 , dengan alat ukur CMM (coordinate measuring machine) tipe Apex504 dengan perangkat lunak Geopak v.3.0.R19 yang memiliki ketelitian 0,0001 mm seperti gambar 4. Nilai springback didapat dari selisih diameter bagian a dan b.

2. Pengukuran kontur.

Pengukuran kontur dilakukan untuk mengetahui bentuk permukaan dinding luar produk uji menggunakan Formtracer tipe SV-C500 dengan perangkat lunak Formpak v.1.213 seperti ditujukkan pada gambar 5 dibawah ini.

(a)

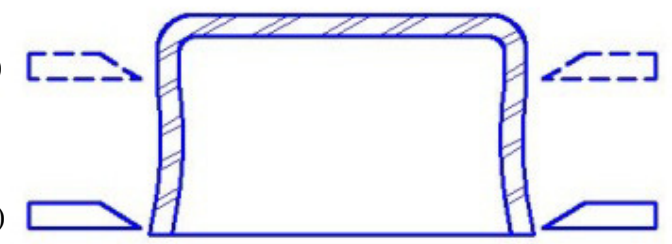

Gambar 3. Posisi ukur produk uji.

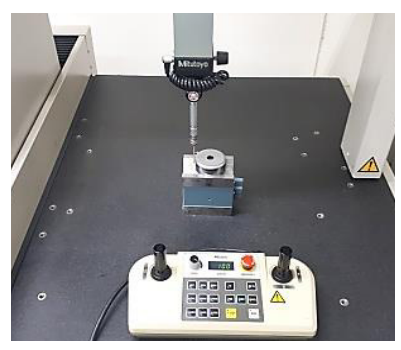

Gambar 4. Pengukuran ukuran linear produk uji dengan $C M M$

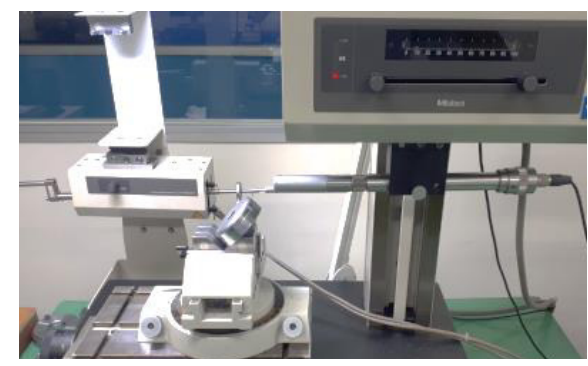

Gambar 5. Pengukuran kontur permukaan dinding luar produk uji dengan formtracer

\subsection{Bahan}

Pada penelitian ini dilakukan kalkulasi dan eksperimen terhadap proses SMF cup silinder dari bahan baja karbon SPCC. Komposisi kimia produk uji cup silinder seperti ditunjukkan pada tabel 2 dan sifat mekanik seperti pada tabel 3 berikut ini : 
Dinamika Teknik Mesin. Mulyanto dan Khaerudini: Investigasi simulasi numeris dan eksperimen proses springback berbentuk cup silider pada lembaran baja karbon SPCC

Tabel 2. Komposisi kimia bahan SPCC dalam \% (Muto dan Naito, 2008)

\begin{tabular}{cccccc}
\hline Unsur & $\mathrm{C}$ & $\mathrm{Mn}$ & $\mathrm{P}$ & $\mathrm{S}$ & $\mathrm{Fe}$ \\
\hline$\%$ & $0,15 \max$ & $0,60 \max$ & $0,100 \max$ & $0,050 \max$ & Balance \\
\hline
\end{tabular}

Tabel 3. Sifat mekanik bahan SPCC (Muto dan Naito, 2008)

\begin{tabular}{llll}
\hline Tebal & Yield point $\left(\mathrm{N} / \mathrm{mm}^{2}\right)$ & Tensile strength $\left(\mathrm{N} / \mathrm{mm}^{2}\right)$ & Elongasi $(\%)$ \\
\hline $0,25-0,30$ & $240 \mathrm{max}$ & $270 \mathrm{~min}$ & $28 \mathrm{~min}$ \\
$0,30-0,40$ & $240 \mathrm{max}$ & $270 \mathrm{~min}$ & $31 \mathrm{~min}$ \\
$0,40-0,60$ & $220 \mathrm{max}$ & $270 \mathrm{~min}$ & $34 \mathrm{~min}$ \\
$0,60-1,00$ & $210 \mathrm{max}$ & $270 \mathrm{~min}$ & $36 \mathrm{~min}$ \\
$1,00-1,60$ & $190 \mathrm{max}$ & $270 \mathrm{~min}$ & $37 \mathrm{~min}$ \\
\hline
\end{tabular}

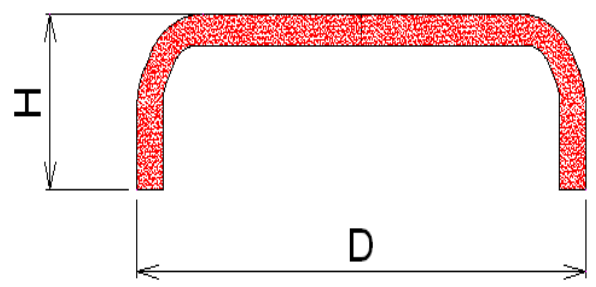

Gambar 6. Geometri produk uji cup silinder, $\mathrm{H}$ adalah tinggi produk uji (15 mm), D adalah diameter luar produk uji $(60 \mathrm{~mm})$.

\section{HASIL DAN PEMBAHASAN}

Gambar 7 memperlihatkan hasil kalkulasi dan eksperimen proses drawing bahan lembaran baja karbon SPCC dengan ketebalan 0,8 mm sedangkan gambar 8 memperlihatkan hasil kalkulasi dan eksperimen bahan lembaran baja karbon $S P C C$ tebal $1,0 \mathrm{~mm}$.

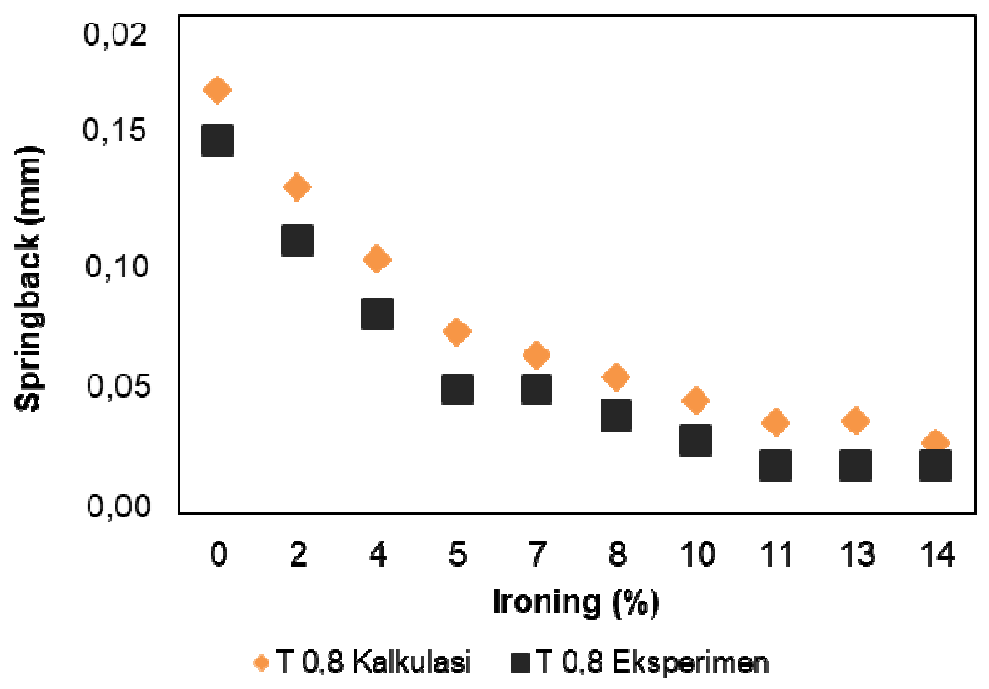

Gambar 7. Hasil kalkulasi dan ekperimen nilai ironing dan springback produk uji cup silinder lembaran baja karbon SPCC tebal 0,8 $\mathrm{mm}$. 
Dinamika Teknik Mesin. Mulyanto dan Khaerudini: Investigasi simulasi numeris dan eksperimen proses springback berbentuk cup silider pada lembaran baja karbon SPCC

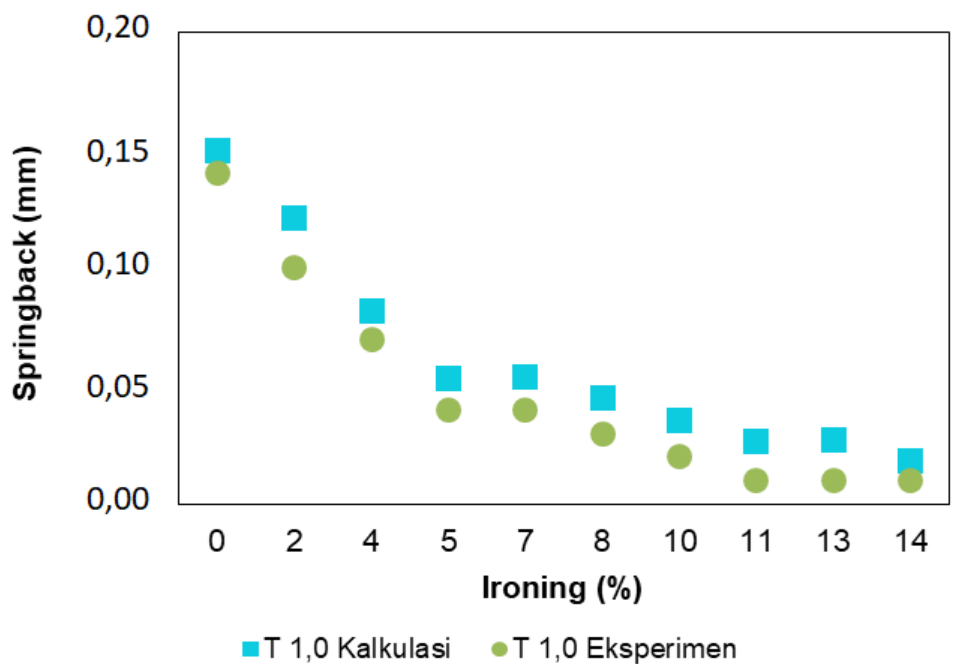

Gambar 8. Hasil kalkulasi dan ekperimen nilai ironing dan springback produk uji cup silinder lembaran baja karbon SPCC tebal $1,0 \mathrm{~mm}$.

Nilai springback menurun sebanding dengan penurunan koefisien gesek dan berbanding terbalik dengan naiknya celah die dan punch, Darmawan dkk. (2018), Mulidran dkk. (2018). Springback meningkat sebanding dengan kenaikan nilai ironing dan blank holder presurre (BHP), Siswanto dkk. (2014). Hasil kalkulasi dan eksperimen proses drawing bahan lembaran baja karbon SPCC dengan ketebalan 0,8 dan $1,0 \mathrm{~mm}$ pada mesin press mekanik $600 \mathrm{kN}$, blank holder pressure (BHF) 2,9 MPa, kecepatan die $60 \mathrm{~mm}$ per menit pada penelitian ini menujukkan fenomena yang sama dengan penelitian sebelumnya yaitu nilai springback meningkat berbanding terbalik dengan peningkatan nilai ironing.

Gambar 9 memperlihatkan hasil pengukuran kontur permukaan hasil proses SMF cup silinder bahan SPCC tebal $0,8 \mathrm{~mm}$ pada ironing $0 \%$ sampai $14 \%$. Sedangkan gambar 10 memperlihatkan hasil pengukuran kontur permukaan untuk bahan tebal 1,0 mm. Fenomena springback pada produk uji dimulai dari pangkal dinding cup silider setelah jari-jari lengkungan dan terus membesar sampai ujung dinding cup silinder.

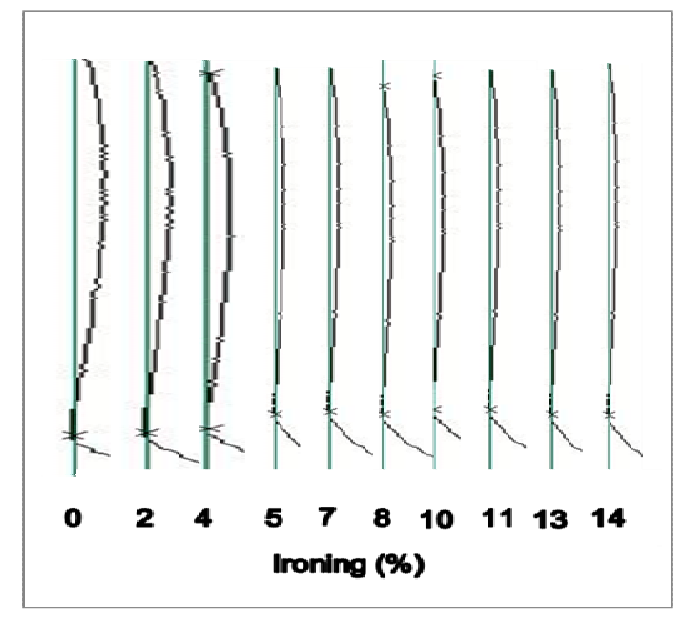

Gambar 9. Kontur permukaan dinding luar produk uji cup silinder tebal 0,8 mm 
Dinamika Teknik Mesin. Mulyanto dan Khaerudini: Investigasi simulasi numeris dan eksperimen proses springback berbentuk cup silider pada lembaran baja karbon SPCC

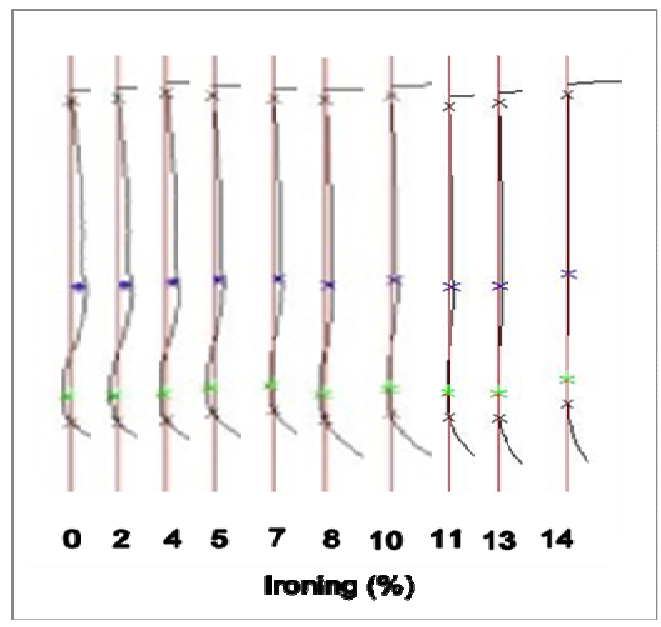

Gambar 10. Kontur permukaan dinding luar produk uji cup silinder tebal 1,0 mm

Pada gambar 7 di atas terlihat bahwa nilai springback hasil kalkulasi lembaran baja karbon SPCC ketebalan 0,8 $\mathrm{mm}$ lebih besar 0,02 $\mathrm{mm}$ ketebalan 1,0 mm. Hal ini disebakan karena lembaran baja karbon SPCC ketebalan 1,0 mm memiliki kekakuan yang lebih besar dari pada $0,8 \mathrm{~mm}$ (Boljanovic, 2004). Gambar 8 memperlihatkan hasil eksperimen lembaran baja karbon SPCC pada proses drawing cup silinder dengan ketebalan $1,0 \mathrm{~mm}$ lebih rendah $0,01 \mathrm{~mm}$ dibanding ketebalan 0,8 $\mathrm{mm}$.

Dari kedua produk uji tersebut menunjukkan bahwa nilai springback hasil perhitungan lebih besar $0,01 \mathrm{~mm}$ dari hasil eksperimen karena tidak semua parameter dalam eksperimen seperti koefisien gesek dan blank holder pressure (BHP) dimasukkan dalam perhitungan. Variabel tersebut juga berbeda dengan penelitian-penelitian sebelumnya. Hasil perhitungan menunjukkan bahwa springback SMF produk uji cup silider linear menurun sebanding dengan kenaikkan nilai ironing. Hasil eksprimen menunjukkan nilai springback cenderung menurun kemudian stabil pada ironing 11, 13 dan $14 \%$.

\section{KESIMPULAN}

Fenomena springback bahan baja karbon SPCC degan ketebalan 0,8 dan 1,0 $\mathrm{mm}$ pada proses drawing menunjukkan bahwa dapat direduksi dengan metode ironing sebesar 0,03 sampai $0,07 \mathrm{~mm}$. Fenomena umum dari eksperimen dan perhitungan untuk bahan tebal $0,8 \mathrm{~mm}$ dan $1,0 \mathrm{~mm}$ menunjukkan ironing $2 \%$ menurunkan nilai springback sebesar $0.04 \mathrm{~mm}$ dan ironing $14 \%$ menurunkan nilai springback $0,13 \mathrm{~mm}$. Dari fenomena tersebut dapat diperkirakan bahwa geometri akhir produk uji dapat sesuai dengan spesifikasi yang dirancang (ditetapkan) dengan keakurasian geometri produk uji diperoleh pada rentang ironing $4-13 \%$.

\section{DAFTAR NOTASI}

H : Tinngi produk uji $(\mathrm{mm})$

D : : Diameter produk uji $(\mathrm{mm})$

$\mathrm{R}_{\mathrm{i}} \quad$ : Jari-jari saat bending $(\mathrm{mm})$

$\beta_{\mathrm{i}} \quad$ : Sudut saat bending $\left(^{\circ}\right)$

$\mathrm{R}_{\mathrm{f}} \quad$ : Jari-jari setelah bending $(\mathrm{mm})$

$\beta_{f} \quad$ : Sudut setelah bending $\left({ }^{\circ}\right)$

T $\quad$ : Tebal bahan $(\mathrm{mm})$

$\Delta \mathrm{R} \quad$ : Perubahan titik pusat jari-jari $(\mathrm{mm})$

a1 : Sudut produk saat bending $\left({ }^{\circ}\right)$

a2 : Sudut produk setelah bending $\left(^{\circ}\right)$

$\Delta \alpha \quad$ : Perubahan sudut produk $\left({ }^{\circ}\right)$

$\varepsilon_{\mathrm{t}} \quad$ : Deformasi permanen

$\varepsilon_{\mathrm{pl}} \quad$ : Deformasi plastis 
Dinamika Teknik Mesin. Mulyanto dan Khaerudini: Investigasi simulasi numeris dan eksperimen proses springback berbentuk cup silider pada lembaran baja karbon SPCC

$\begin{array}{ll}\varepsilon_{\mathrm{e}} & : \text { Deformasi elastis } \\ \mathrm{L}_{\mathrm{n}} & : \text { Garis netral } \\ \mathrm{K}_{\mathrm{S}} & : \text { Faktor springback } \\ \mathrm{IR} & : \text { Ironing rasio }(\%)\end{array}$

\section{DAFTAR PUSTAKA}

Boljanovic V., 2004, Handbook sheet metal forming processes and die design, Industrial press inc, New York.

Coera J., Laurenta H., Oliveirab M.C., Manacha P.Y., Menezes L.F., 2018, Detailed experimental and numerical analysis of a cylindrical cup deep drawing: pros and cons of using solid-shell elements, International Journal of Material Forming, 11(3), 357-373.

Darmawan A., Anggono, A., Hamid, A., 2018, Die design optimization on sheet metal forming with considering the phenomenon of springback to improve product quality, In The $2^{\text {nd }}$ International Conference on Engineering and Technology for Sustainable Development, Bahan Science, Engineering and Chemistry, 154, 1-4, Jogjakarta.

Muto K., Naito T., 2008, Japan industrial standard, Ferrous material and metallurgy, Akasaka, Minatoku, Japan.

Mulidran P., Spisak E., Majernikova J., Tomas M., Slota J., 2018, Springback Prediction Of Formed Tailor Welded Blanks, The International Journal Engineering and Science, 7(11), 31-35.

Siswanto W.A., Anggono A.D., Omar B., Jusoff K., 2014, An alternate method to springback compensation for sheet metal forming, The Scientific World Journal, 301271,1-13.

Wagoner R.H., Lim H., Lee M.G., 2013, Advanced issues in springback, International Journal of Plasticity, 45, 3-20.

Zein H., El-Sherbiny M., Abd-Rabou M., El-Shazly M., 2013, Effect of die design parameters on thinning of sheet metal in the deep drawing process American Journal of Mechanical Engineering,1(2), 20-29. 